\title{
Imperial Discomfort in Post-Habsburg Tianjin
}

\author{
Miloš Jovanović
}

This visual essay explores the incommensurability of imperial legacies by assembling photographs taken by an inexperienced researcher of Serb/Yugoslav origin in Tianjin (天津), northern China. The images were collected during a research trip in February 2017, as part of a research project on spaces of imperial historicity in former Habsburg cities. The essay represents a visual archive of my discomfort at encountering the intimate legacies of globally unequal colonial heritage.

I begin this intervention with an autoethnography, juxtaposing my memory and field notes to the cultural and social forces which construct my subjectivity as photographer/researcher (Fisher 2015). I focus on my recognition of the research space as "familiar", mediated by historical and personal narratives of imperial and socialist cityscapes. The essay proceeds to explore how such familiarity is broken, revealing how relations between (post-)imperial subjects remain incommensurable. Finally, I explore how imperial subjectivities inform transnational research practices, stressing the phenomenology of photographic practice. Ultimately, this essay interrogates the limits of visual research practices, as conducted by persons subjectivized by imperial legacies of hierarchized and territorialized difference. 


\section{Familiar Spaces}

My arrival at Beijing Airport evokes other times and places. In the main hall, the sight of PRC flags transports me to Belgrade in 1999, the bomb shelter below my socialist-era high-rise. I recall being huddled over the only radio alongside our neighbours, listening to crackly reports of US Air Force missiles destroying the Chinese embassy. ${ }^{1}$ A strong sense of righteous privilege comes over me as I pass Americans and West Europeans, standing in long visa lines. Owing to Serbia's close economic and political ties with China, its citizens enjoy visa-free travel. I am overwhelmed by feelings of socialist solidarity, anti-imperialism, and brotherhood.

My narrative echoes the internationalist discourse of my youth during the rule of Slobodan Milošević, when Yugoslavia sought to establish a counter-hegemonic bloc with China, North Korea, Libya, and Iraq. Sharing much of its developmentalist logic with Edvard Kardelj's visions for the Non-Aligned Movement, Miloševićs anti-colonial internationalism masked internal violence and economic exploitation within the Yugoslav state.

Feelings of pride over the achievements of state socialism grow on the bus to Beijing South railway station. I feel at home looking out the window at modernist housing blocks, following the third and second ring roads. Even the high-speed bullet train to Tianjin, an unimaginable feat of technology in former Yugoslavia, seems fa-

1 On 7 May 1999, B-2 bombers flying out of Whiteman, Missouri, launched five missiles at the south end of the Chinese Embassy in Belgrade, located on Trešnjinog Cveta Street. The missiles killed Xinhua journalists Shao Yunhuan (邵云环), Xu Xinghu (许杏虎), and Zhu Ying (朱颖) and injured some twenty other embassy staff. The bombing was followed by massive protests in China, quelled by authorities after a formal apology and a multi-million-dollar indemnity payment by the United States. 
miliar. In preparation for my research trip, I have read extensively about rising inequality in contemporary China. Yet, the passing architecture lulls me into a sense of comfort. I find socialist intimacy in the long tracts of modernist high-rises that pass by the window, knowing full well the domicide in which they originate.

Upon arrival in Tianjin, I rush impatiently to the site of my research, the Héběi district, a heritage space of nineteenth-century imperial globalization. Between 1901 and 1917 (de jure 1920), a central part of the city was an Austro-Hungarian concession. Split between eight imperialist powers after their suppression of the Boxer Rebellion, Tianjin was a hypercolony (Rogaski 2004), a place where empires positioned themselves against one a nother in close proximity. In the words of Austro-Hungarian vice-consul Karl Bernauer, the banks of the Hăihe (Peiho) river were laden with potential for "profitable business".

Motivated by profit and the need to affirm their status as a European power (Sauer 2012), the Habsburgs sought to create "civilized", industrial urban space in Tianjin. Between 1905 and 1917, the Austro-Hungarian concession was built up by the Hotung Baugesellschaft (奥界建造公司), a development company run by a navy officer, the Rijeka-born Hugo Accurti. The firm participated in the development of Baron von Czikanny Straße (today's Shengli Road, 胜利路), the construction of the city's tramway line, the quay and the International Bridge over the river. Imperial profit was facilitated by the presence of Habsburg navy officers and marines, many of them South Slavs.

Walking through the former concession a rea, I seek out Habsburg architecture, the buildings and streets produced after the violent

2 At-OeSTa. HHStA-Diplomatie und Außenpolitik 1848-1918 GsA Peking 103-1, 9. 
suppression of the Boxers. They are not only objects of scholarly interest but also visual examples of a shared post-imperial subjectivity. I near the end of the former Habsburg quay, which today constitutes the "Austrian Style Riverfront" area of cultural preservation. Across the former International Bridge, the Art Nouveau consulate building and former concession headquarters immediately evoke memories of Zemun. I immediately notice the interplay of rounded and rectangular elements, the decorative cornice and window surrounds with stylized floral motifs, and a large figure of a violin player on the facade.

A Habsburg town incorporated into Yugoslav Belgrade in 1934, Zemun was my mother's home in the 1970s, my father's workplace in the early 2000s, and is my sister's today. The town's civilizational distinctiveness from the rest of Belgrade, its imperial cityscape, had long been part of our family discussions. In Tianjin, the straight-lined Shengli Road evokes memories of Ruma. Established by German settler colonists in 1746, the Syrmian home of my paternal family is laid out in long straight rows of single houses, akin to the Tianjin thoroughfare. Focusing on geographically distant but intimately familiar architecture, I imagine a shared post-imperial subjectivity. Any incommensurate differences become subsumed by feelings of relatability, and I rush to snap a few photographs. Yet I am frustrated with the resulting images, which fail to capture the sense of familiarity I share with the cityscape.

\section{A Troubling Focus}

In the Tianjin City Museum, I a m confronted with my whiteness. A permanent exhibit features photographs of dead bodies, mangled by the bombs of the Eight Nations' Alliance, many launched by Croat and Serb sailors. Later, in the Viennese archives, my 
discomfort returns. I read the letter of a volunteer for navy service in Tianjin whose last name ends with -ić, just like mine. Within the Habsburg monarchy, Slavs, Romanians, and Roma, among others, were subjected to cultural subalternity, assimilative and civilizing projects as "ahistoric" peoples, including acts of mass indiscriminate violence during wartime (Reisenleitner 2002; Glajar 2004: 5-7; Okey 2007; Holzer 2008). Yet, on the global stage, those very same subalterns freely participated in the subjection of others (Baker 2018: 78-79, 167-169). In understanding the interplay between local and global constructions of whiteness, such histories reflect the incommensurability of (post-)imperial experiences.

Since my return from the field, I have continued to reflect on this tension between discomfort and familiarity. More than a relation between researcher and the object of their research, imperial discomfort is always situated within a broader global context of hierarchized difference. As Catherine Baker has noted, we cannot explain Yugoslav "position(s) within those global legacies of colonialism and slavery if we exempt [them] from global formations of race" (2018: 9). Serbs, especially light-skinned ones like myself, have not been subject to racialization in a global context. Conversely, the racialization and hyperexploitation of Chinese labour have played a historically constitutive role in global imperialism (Jung 2009). Mediated through architecture, my familiarity obscured uneven legacies of racialized subjectivities.

Visual archives of imperial architecture necessarily bring forth comprehension and occlusion, heightening the ambivalence of imperial legacies. ${ }^{3}$ At their core is a double signifier of familiarity: the physical structure as a recognized object of historicity versus

3 See the special issue "Ambivalent Legacies: Political Cultures of Memory and Amnesia in Former Habsburg and Ottoman Lands", History es Anthropology, 30: 4 (2019). 
the photographic image, an everyday form of disengaged representation. The Austrian-style cityscape of Tianjin obscures the conditions of its production, which in the early twentieth century bounded Škoda's weapons factories and Zhili warlords. The architectural photograph operates similarly - curated by the researcher's gaze, it privileges material legacies above the social relations that produced them. Discomfort thus necessarily emerges from any visual archive of imperial heritage, the costs of empire always unaccountable, its social legacies never fully comprehensible.

Transnational research practices emphasize scholars' ability to bridge or comprehend imperial difference through historiographical, linguistic, or cultural expertise. Individual competition within capitalist academia privileges such interpretations of success, in which researcher subjectivity is seen as secondary to mastering the archive. ${ }^{4}$ Yet, embracing the discomfort I felt in Tianjin opens up a meaningful archive within of individual (post-)imperial subjectivity and my failure to grasp the research field. In photographing Austro-Hungarian architecture, my aesthetic concern for "proper" documentation came to be frustrated by other lived experiences and different post-imperial lives.

The rejected photographs of my visual archive offer an imprint of researcher subjectivity as it participates in the mediation of Tianjin's Austro-Hungarian past. Presented here as a visual essay, the following ten images fail to capture the city's imperial legacy as their intended subject. Such failure is reflected in "awkward" framing and composition, "misfired" timing, and "inappropriate" subject selection. These are not only technical glitches, nor do they testify to the researcher's lack of skill alone. Rather, they exemplify my own affective discomfort, an aspect of visual urban research generally obscured from publication.

4 For an important exception, see Burton and Kennedy (2016). 
The captions describe why each image was rejected and note the subsequent action which produced a "proper" take. In doing so, this essay emphasizes discomfort as an intimate and curatorial experience, emerging out of a personal mediation of imperial pasts. Ultimately, the essay calls attention to the phenomenological aspects of incommensurate subjectivities, as they pertain to (post-)imperial research.

\section{Acknowledgements}

I am grateful to Mervay Mátyás and Xu Yangqing for their kind guidance in all matters Tianjin, Jovana Mihajlović Trbovc for reflecting on her experiences in Rwanda with me, Pelin Tiğlay for advising me to focus on my ignorance, and Jeremy F. Walton and Giulia Carabelli for their comments on the first draft of this essay.

MILOŠ JOVANOVIĆ is Assistant Professor of History at the University of California, Los Angeles and former member of the Max Planck Research Group 'Empires of Memory'. He can be reached via loshmi.net 


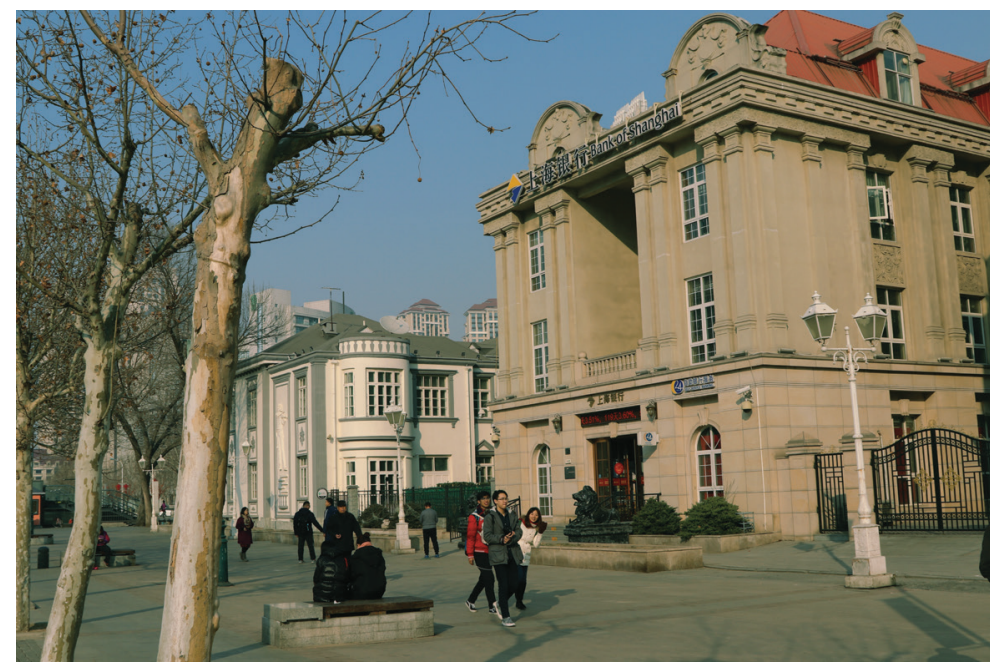

Figure 1: The neo-historicist bank building, barren trees, and curious passers-by distract from the white and grey Austro-Hungarian consulate. In the next take, I walk closer to the Habsburg building, so that it fills the frame.

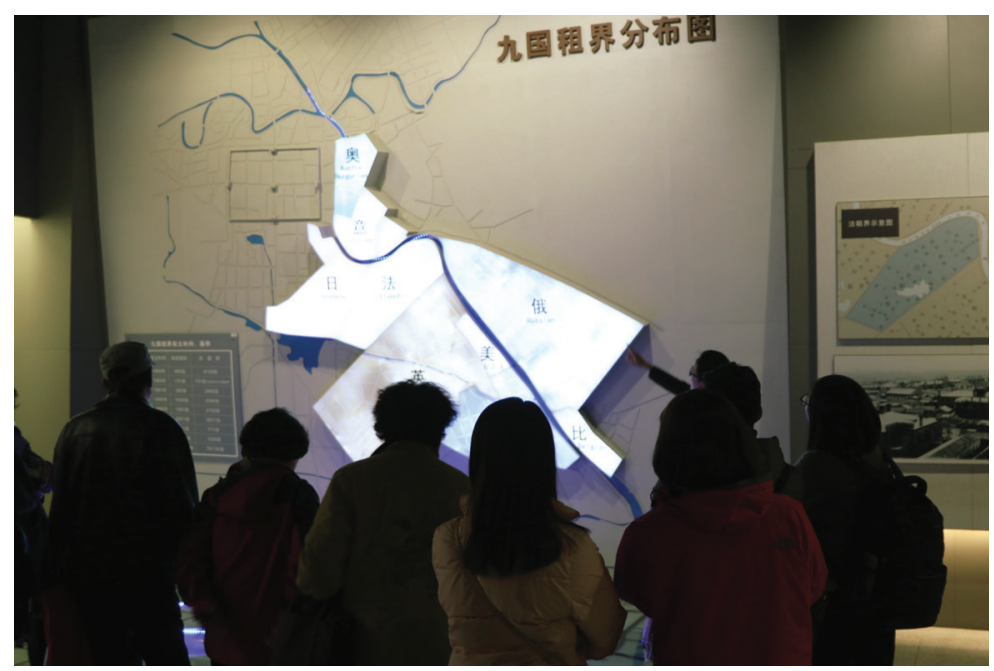

Figure 2: In the low light, I mistakenly focus on the back of the woman's head in the centre of the image instead of the museum map. The map shows Tianjin's division among eight colonial powers. In the next take, I zoom in on Austria-Hungary at the very top, leaving the museum visitors blurry. 


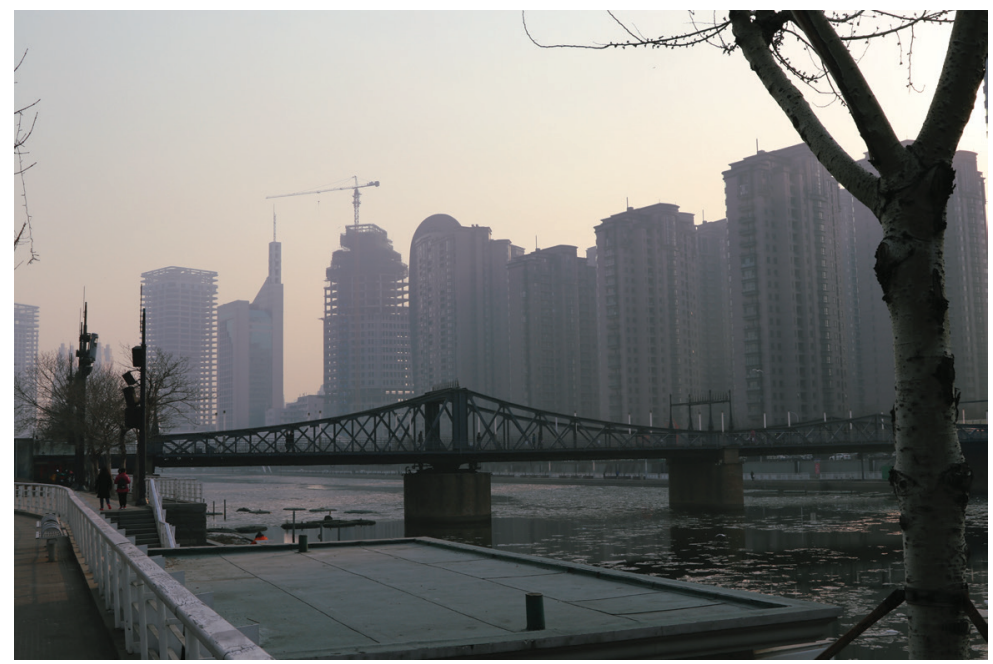

Figure 3: I am frustrated by this framing of the former International Bridge (today's Jintang Bridge 金汤桥). The bridge joined the Austro-Hungarian concession to the Chinese town. Instead of dramatic contrast between skyscrapers and imperial heritage, the image is disturbed by a bland tar roof. In the next take, I change positions to crop the roof out.

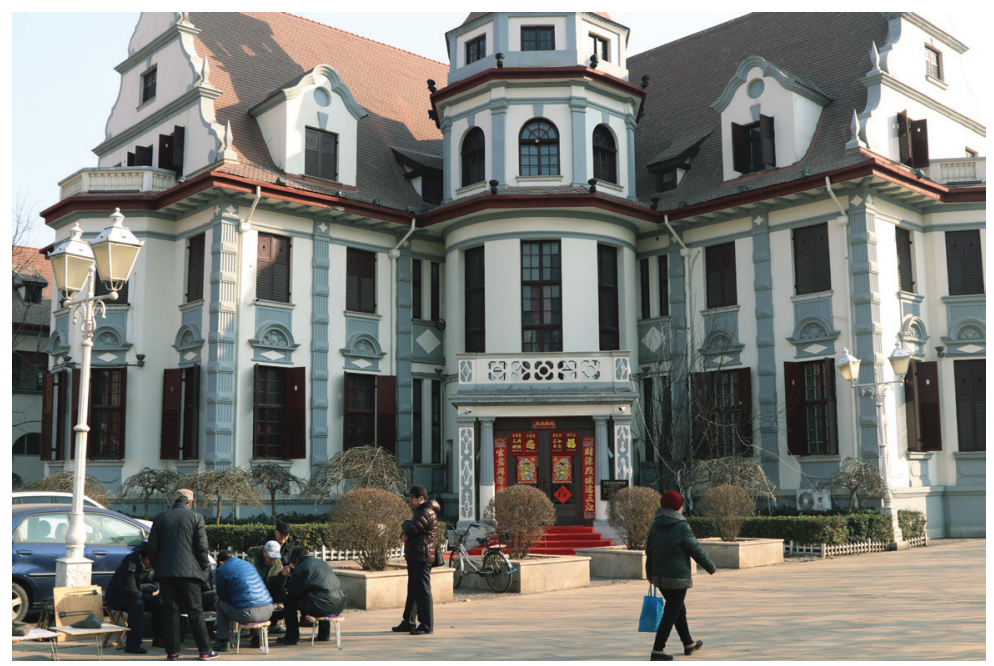

Figure 4: There is not enough space behind me to capture both the historic Yuan Shikai Residence in the background and the mahjong players in front. I am forced to crop both the feet of passers-by and the top of the building. In the next take, I reposition myself so the whole building fits into the frame. 


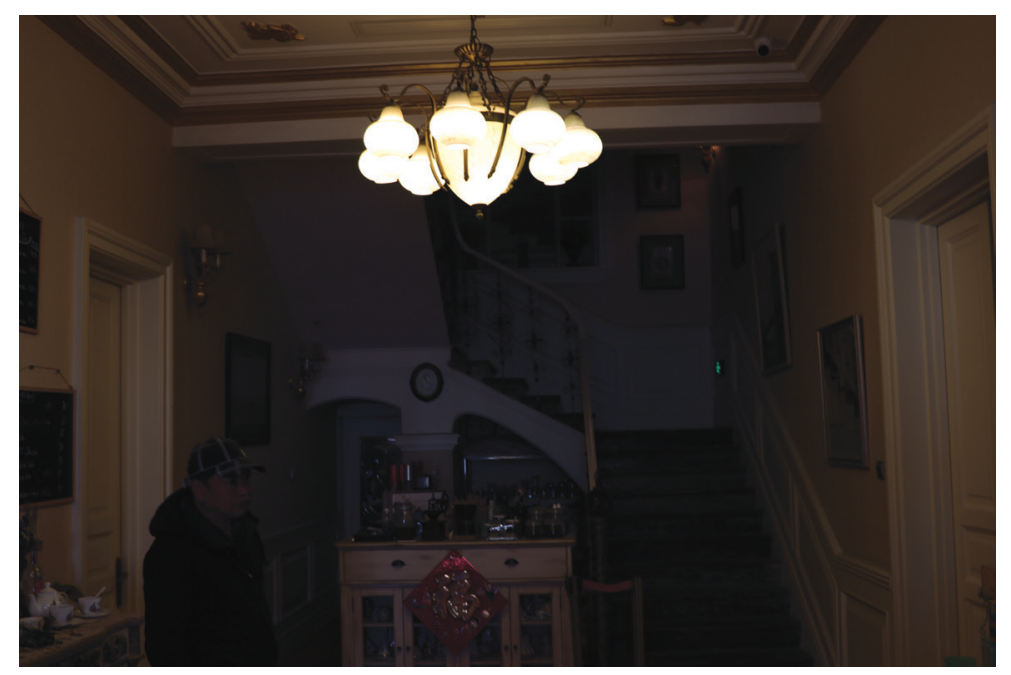

Figure 5: I rush to photograph the interior of the former Austro-Hungarian consulate, but measure the light incorrectly as its custodian enters the foyer. In the next take, I wait for him to leave the room.

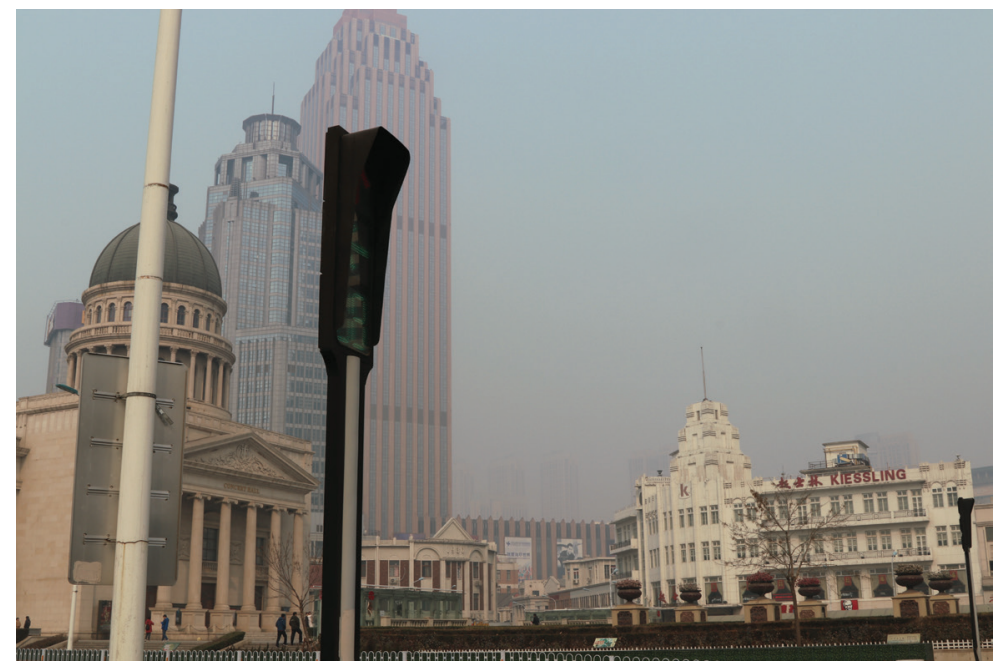

Figure 6: Instead of framing the scene neatly, a streetlight and lamppost disturb the contrast I envisioned between skyscrapers and British imperial architecture. In the next take, I crop them out of the frame. 


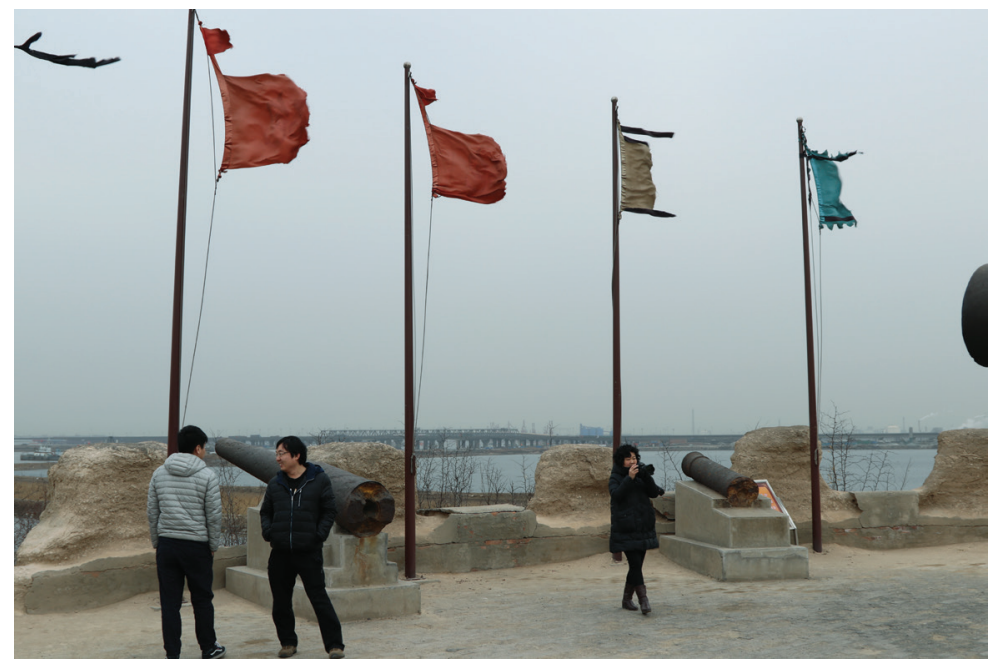

Figure 7: People having fun distract from the memorial spectacle of the Taku forts (大沽炮台), captured by an initial Austro-Hungarian and Russian onslaught in June 1900. I wait for them to look away, so the mood will appear more reflective.

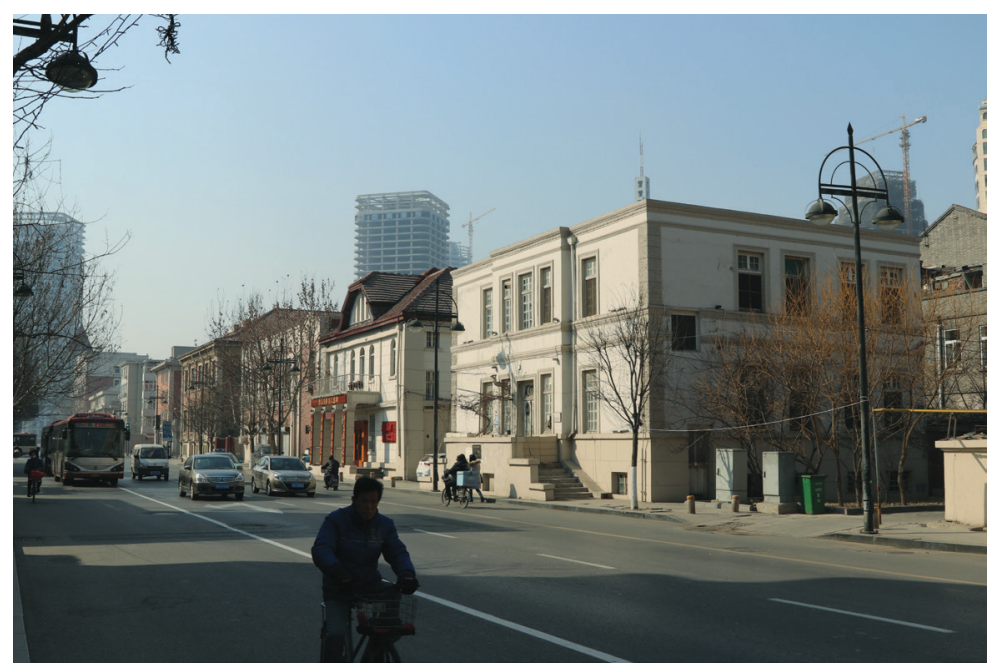

Figure 8: A man bikes into frame as I rush to photograph Austro-Hungarian residences on Shengli Road, the former Baron von Czikanny Straße. I am frustrated by the traffic and wait for a red light before recomposing the shot to focus on the buildings. 

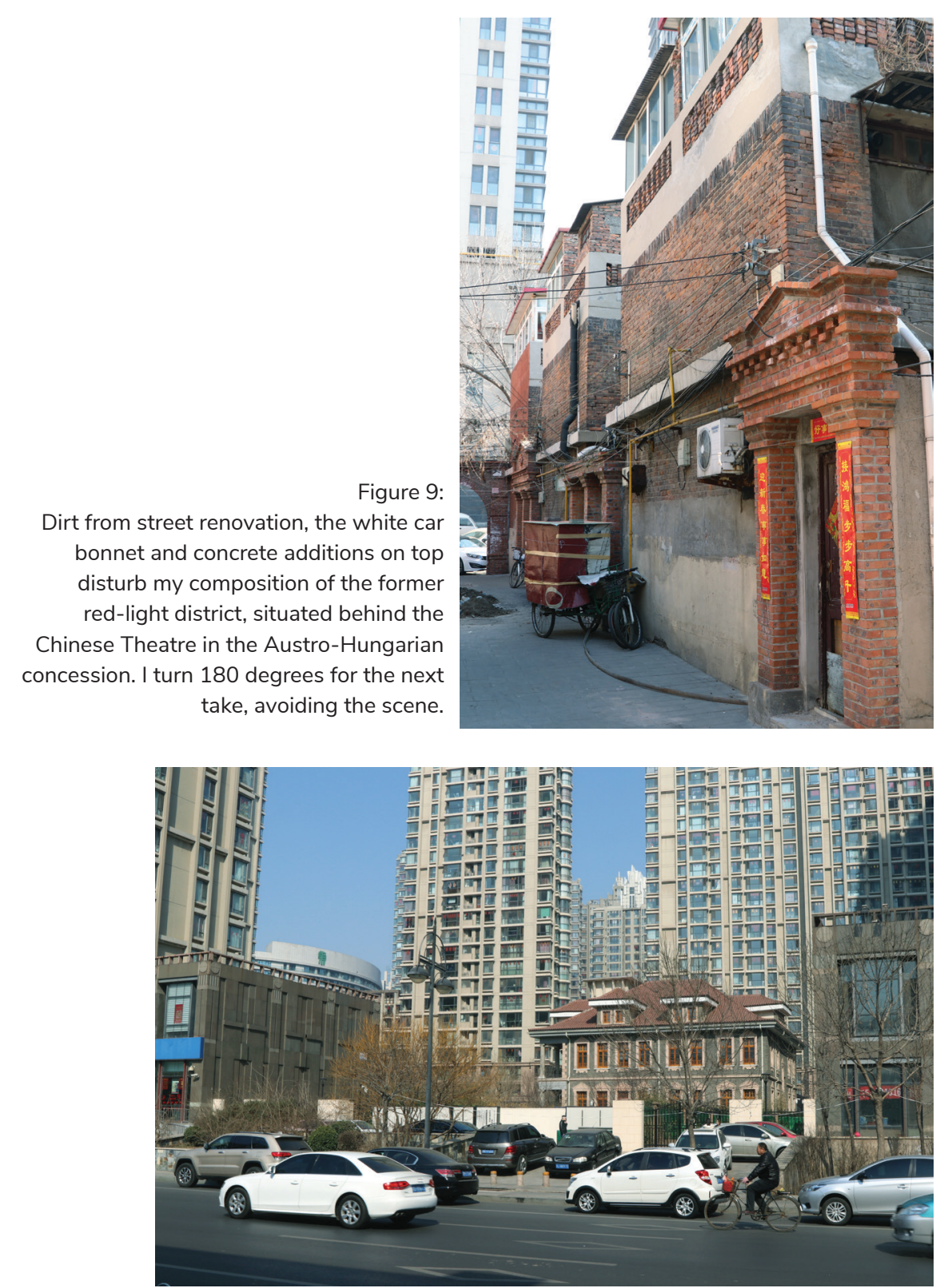

Figure 10: The bright new cars and low contrast between various structures make the former Austrian Officers' Club, a grey building with orange windows, appear small and insignificant. I am unable to take a closer shot as the structure is fronted by an opaque fence. I abandon the effort to photograph it further. 


\section{References}

Baker, Catherine. 2018. Race and the Yugoslav Region: Postsocialist, Post-Conflict, Postcolonial? Theory for a Global Age. Manchester: Manchester University Press.

Bernauer, Karl. January 1903. “Vice-consul Bernauer an Graf Gołuchowski", At-OeSTa. HHStA-Diplomatie und Außenpolitik 18481918 GsA Peking 103-1.

Burton, Antoinette and Kennedy, Dane, eds. 2016. How Empire Shaped Us. London: Bloomsbury Academic.

Fisher, Karen T. 2015. "Positionality, Subjectivity, and Race in Transnational and Transcultural Geographical Research", Gender, Place \& Culture 22, no. 4 (April): 456-473.

Glajar, Valentina. 2004. The German Legacy in East Central Europe as Recorded in Recent German-Language Literature. Rochester, NY: Camden House.

Holzer, Anton. 2008. Das Lächeln der Henker: der unbekannte Krieg gegen die Zivilbevölkerung 1914-1918. Darmstadt: Primus Verlag.

Jung, Moon-Ho. 2009. Coolies and Cane: Race, Labor, and Sugar in the Age of Emancipation. Baltimore, MD: JHU Press.

Okey, Robin. 2007. Taming Balkan Nationalism. Oxford: Oxford University Press.

Reisenleitner, Markus. "Central European Culture in Search of a Theory, or: The Lure of 'Post/Colonial Studies." Spacesofidentity.Net, 1 August 2002. https://doi.org/10.25071/1496-6778.8030.

Rogaski, Ruth. 2004. Hygienic Modernity: Meanings of Health and Disease in Treaty-Port China. Oakland, CA: University of California Press.

Sauer, Walter. 2012. “Habsburg Colonial: Austria-Hungary's Role in European Overseas Expansion Reconsidered", Austrian Studies 20: 5-23. 